\title{
Gulag ja Suomi -seminaari Helsingissä
}

Helsingissä keskustakirjasto Oodissa, Kino Regina -salissa järjestettiin 29.1.2020 yleisöseminaari aiheesta, josta edellisenä syksynä oli käyty vilkasta keskustelua Suomessa. Seminaarin teemana oli nimittäin Neuvostoliiton vankileirijärjestelmän, gulagin historia ja suomalaisten uhrien kohtalo Stalinin vainoissa. Puhujina oli sekä suomalaisia että kansainvälisiä tutkijoita ja toimittajia. Sali oli ääriään myöten täynnä ja tiiviistä aikataulusta huolimatta myös keskustelua ehdittiin käydä.

Seminaariin liittyi kiinnostava elokuvaohjelmisto DocPoint-festivaalilla ja Kansallisen audiovisuaalisen instituutin KAVI:n sarjassa. Kino Reginan aulaan oli myös pystytetty VilleJuhani Sutisen valokuvanäyttely hänen ja Ville Ropposen tekemältä matkalta gulagin jäljille Venäjälle. Osa valokuvista oli julkaistu samojen tekijöiden teoksessa Luiden tie (Like, 2019). Oodi puolestaan kokosi näyttelyn suomennetuista Gulag-aiheisista teoksista.

\section{Taustaa seminaarille}

Ajatus kansainvälisestä seminaarista, jossa nostettaisiin esille gulagin yleistä historiaa ja sen merkitystä erityisesti suomalaisille oli kypsynyt jo muutaman vuoden ajan meidän järjestäjien, professori Kristian Feigelsonin ja elokuvaohjaaja Kanerva Cederströmin välisissä keskusteluissa. Alun perin lähtökohtana oli ollut pohtia gulagin historiaa ja muistia käsittelevän historiantutkimuksen ja elokuvan välisiä yhteyksiä, koska molemmat toimimme työssämme elokuvan parissa. Feigelson on neuvostoelokuvaan erikoistunut elokuvan sosiologian professori Sorbonne Nouvelle yliopistosta Pariisissa. Minä puolestani olen käsitellyt paljon historiaa ja muistia elokuvaohjaajana elokuvissani ja opetuksessani dokumentaarisen elokuvan professorina Aalto-yliopiston Taiteiden ja suunnittelun korkeakoulussa (TaiK) vuosina 2003-2010.

Keskusteluissamme tuli esille, miten suuri merkitys elokuvalla on "muistin teatterina" historiatietoisuuden rakentamisessa, rinnan historiantutkimuksen kanssa. Keski-Euroopassa, erityisesti Ranskassa, Gulagiin erikoistuneet historiantutkijat ovat jo kauan käyttäneet niin arkistoelokuvamateriaalia kuin fiktiivisiäkin elokuvia lähteinään ja inspiraationaan. Halusimme siksi liittää seminaarin yhteyteen elokuvaohjelmiston, joka koostuisi niin neuvostoelokuvan gulag-representaatioista, Perestroikan jälkeen saataville tulleesta arkistomateriaaliin pohjaavista elokuvista kuin uudemman tekijäpolven näkemyksistä gulagin henkisestä perinnöstä.

Ajan mittaan kävi kuitenkin ilmi, että Suomessa oli suuri tarve käsitellä myös erikseen monia gulagin historiaan ja Suomeen liittyviä erityispiirteitä, joita meillä ei yleisemmin tunnettu tai oltu käsitelty lainkaan.

Suomessa on elänyt ja elää kymmenientuhansien teloitettujen, kadonneiden tai leireiltä palanneiden omaisia, stigmatisoituneina ja tietämättöminä läheistensä kohtaloista, mykkinä. Gulagissa surmattujen suomalaisten ja suomensyntyisten tuhoamisesta ei ole muodostunut osaa kansallisesta muististamme eikä osaa kansamme historiasta. Tämän hiljaisuuden ja tietämättömyyden syitä on varmasti pohdittava vielä useasti erikseen, mutta päädyimme ottamaan seminaarimme ohjelmistoon kansainvälisen tutkimuksen esittelyjen rinnalle myös suomalaisten tutkijoiden ja toimittajien puheenvuoroja gulagin ja suomalaisten suhteesta.

\section{Tilanne Suomessa}

1990-luvulle sijoittuvalla ensimmäisellä vuosikymmenellä Neuvostoliiton romahduksen jälkeen, Mauno Koiviston annettua inkerinsuomalaisille luvan palata Suomeen ja KGB:n arkistojen avauduttua Venäjällä niin tutkijat kuin toimittajatkin ryhtyivät paneutumaan Stalinin ajan rikoksiin ja suomalaisten kohtaloihin vainoissa. Suomessa oli toki jo aiempina vuosikymmeninä, aina 1920-luvulta alkaen, julkaistu lukuisia muistelmateoksia leireiltä palanneilta, mutta ne olivat jääneet marginaaliin tai kokonaan unohduksiin - ja jopa sensuuriin sodan jälkeen. Yleisradiossa tuotettiin 1990-luvun alkuvuosina useampia TV- ja radio-ohjelmia gulagin suomalaisista uhreista ja heidän omaisistaan. Eila LahtiArgutina julkaisi vuonna 2001 teoksen Olimme joukko vieras vaan (Siirtolaisinstituutti), joka sisälsi matrikkelin yli 800 suomalaisen uhrin ni- 
mestä. Yhdessä toimittaja Jukka Rislakin kanssa hän oli julkaissut jo vuonna 1997 teoksen Meillä ei kotia täällä(Otava) suomalaisten loikkareiden joukkotuhosta Uralilla. Vuonna 2001 Erkki Vettenniemi väitteli vankileiriltä palanneiden suomalaisten muistelmien politiikasta (Surviving the Soviet Meat Grinder: the Politics of Finnish Gulag Memoirs, Aleksanteri-instituutti). Kirjailija Anita Konkka oli julkaissut useampiakin romaaneja Neuvostoliitossa eläneiden inkeriläisten sukulaistensa muistelmien pohjalta. Vaikutti siltä, että nyt alkaisi uusi aikakausi tukahduttavan suomettumisvaiheen jälkeen, jolloin vihdoinkin saataisiin laajemmin yleisölle tietoa suomalaisten ja suomalaissyntyisten kohtaloista 1920-1950 luvuilla Neuvostoliitossa. Mutta kun KGB:n arkistot Jeltsinin luovuttua vallasta alkoivat osittain sulkeutua, tyrehtyivät monen tutkimusmahdollisuudet ja sitä myötä myös keskustelu maassamme.

Gulag ja neuvostovallan hirmuteot nousivat esille pitkästä aikaa vuonna 2018 juhlittaessa Aleksander Solženitsynin 100-vuotissyntymäpäivää Suomalaisen Kirjallisuuden Seuran (SKS) seminaarissa marraskuussa. Samalla voitiin nostaa myös esille kirjailija Sofi Oksasen aloitteesta vuonna 2012 uudelleen julkaisema Vankileirien saaristo -teos, joka oli ollut käänteentekevä tapahtuma jo aikanaan. Vähän aikaisemmin oli julkaistu Antti Tuurin romaani Ikitie (Otava). Vuonna 2017 Antti-Jussi Annala ohjasi sen pohjalta samannimisen elokuvan, joka saavutti jo laajemman ja nuoremman yleisön. Säde-kommuunin suomalaisten ja amerikan- ja kanadansuomalaisten Neuvosto-Karjalan rakentajien joukkomurhat 1930-luvun Suuren terrorin aikana saivat myös monet nuoremman polven edustajat kiinnostumaan näistä historian ja usein myös omien sukujensa vaiheista.

Samoihin aikoihin Suomeen alkoi levitä tietoa Venäjän Memorial-yhdistyksen ja Joffe-säätiön kautta Karjalan Sandarmohista ja Karhumäestä löydetyistä joukkohaudoista sekä vuosien aikana tehdyistä kaivauksista alueella ja siellä teloitettujen suomalaisten henkilöllisyyksistä. Elokuussa 2019 osallistuttiin Suomessa ensimmäistä kertaa eri puolilla maata kansainväliseen internetissä järjestettyyn Sandarmohin joukkohautoihin ammuttujen uhrien muistotapahtumaan, nk. "nimien lausumiseen". Satojen suomalaisten nimiä lausuttiin eri puolella maatamme. Suurin osa niistä oli peräisin Eila Argutina-Lahden toimittamasta matrikkelista Olimme joukko vieras vain. Media heräsi meilläkin ja suomalaisten ja suomalaissyntyisten gulagin uhrien kohtaloista alettiin kirjoittaa ja puhua. Ilmestyi nuoren pol- ven kirjailijoiden Ville-Juhani Sutisen ja Ville Ropposen Luiden tiellä, joka on matkakirjan muodossa ensimmäinen suomalaisten tekijöiden teos Gulagin historiasta. Sen Tieto-Finlandiaehdokkuus merkitsi myös harppausta laajemman yleisön gulag-tietoisuudessa.

\section{Gulagin historia ja muisti Suomessa}

Seminaarimme tammikuussa 2020 oli herättänyt siis jo paljon kiinnostusta syksyisen keskustelun pohjalta. Juuri ennen sitä oli myös avattu Kansallismuseossa Lea Pakkalan ja Meeri Koutaniemen näyttely inkeriläisten kohtaloista leireillä ja karkotuksessa Neuvostoliitossa. Seminaarin puheenvuoroissa käsiteltiin sekä kansainvälistä että suomalaista gulag-tutkimusta.

Dosentti Markku Salomaa avasi seminaarin historiallisella katsauksella leirijärjestelmän syntyyn ja terrorin syihin ja seurauksiin. Tutkija Irina Flige Joffe säätiöstä ja Memorialyhdistyksestä Pietarista selvitti joukkohautojen tutkimuksen vaikeuksia. Vaikeudet johtuvat niin maantieteellisistä syistä kuin virallisten valtiollisten tilastollisten tietojen ja henkilötietojen puutteesta. Professori Nicolas Werthin (Le Centre national de la recherche scientifique, CNRS, Pariisi) aiheena oli gulagin kriisi vuoden 1954 jälkeen. Kriisi syntyi hallinnollisesti raskaan ja tuottamattoman leiriorganisaation, vankileirijärjestelmän uudelleenorganisoinnin sekä vankien asteittaisen ja valikoivan vapauttamisen seurauksena. Professori Judith Pallot (Oxford University/Aleksanteri-instituutti) esitteli Helsingin yliopiston Aleksanteri-instituutissa meneillään olevaa EU-rahoitteista tutkimusprojektiaan, joka selvittää Venäjän vankilajärjestelmän suhdetta gulagin konkreettiseen ja henkiseen perintöön. Hän puhui neo-gulag -käsitteen ongelmallisuudesta ja toisaalta stalinistisen kauden leirijärjestelmän jättämistä perinteistä.

Stepan Cernousek Prahasta esitteli virtuaalista Gulag-projektia, jossa "rekonstruoidaan" tuhoutumassa olevia leirejä Siperiassa. Tohtoriopiskelija Susan Ikonen (Helsingin yliopisto) valotti suojasään jälkeiseen kulttuuriin ja leirikirjallisuuden julkaisemisen politiikkaan liittyviä vaiheita Hruštšovin puheesta Brežnevin valtakauden alkuun. Valtiotieteiden tohtori Erkki Vettenniemen aiheena oli suomalaisten leirivankien, "toppatakkien" paluu kotimaahan vuoden 1954 jälkeen, tämän paluun käsittely maamme lehdistössä sekä leirimuistelmien julkaiseminen 1950-luvulla. Tohtori Amo Ruusunen selvitti kuulijoille internetistä löytyviä mahdollisuuksia etsiä entisessä Neuvostoliitossa kadonneita ja 
kuolleita henkilöitä.

Kirjailija, toimittaja Ville Ropponen esitteli Suomalaisten kansojen vapautusliiton eli Sofinsalaliittojuttua, joka kehiteltiin kokoon vuosina 1931-34. Järjestön väitettiin suunnitelleen Neuvostoliiton suomensukuisten kansojen yhdistämistä Suomen alaiseksi "protektoraatiksi" aina Karjalasta Jeniseijoelle Siperiaan asti. Sofinsalaliiton vuoksi vangittuja teloitettiin myöhemmin Stalinin vainoissa. Suuren terrorin aikana Sofin-salaliittoa käytettiin lisäksi yhtenä tuomion osaperusteena. Tällöin siihen yhdistettiin jopa tuhansia ihmisiä. Jukka Rislakin puheenvuoro suomalaisten vangitsemisista, kuulusteluista ja tuomioista julkaistaan ohessa.

Seminaari päättyi keskusteluun, johon osallistuivat Ilta-Sanomien toimittaja Arja Paananen, toimittaja Lea Pakkanen, kirjailija-toimittaja Ville Ropponen ja kirjailija Ville-Juhani Sutinen.

Seminaari on kokonaisuudessaan katsottavissa YouTubessa osoitteessa:

https://youtu.be/1OxdgOT_5Ek

Kanerva Cederström

\section{Suomalaiset Stalinin suuressa vainossa}

Tämän kirjoituksen taustalla on Helsingissä järjestetyn Gulag ja Suomi - historia ja muisti -seminaarin järjestäjien pyyntö puhua suomalaisten kohtaloista Stalinin vainoissa. Monet tässä kirjoituksessa käyttämäni tiedot ihmiskohtaloista ovat peräisin venäläisistä arkistoista ja käytimme niitä, kun kirjoitimme Eila Lahti-Argutinan kirjaa Meillä ei kotia täällä. Suomalaisten loikkarien joukkotuho Uralilla 1938 (Otava 1997). Lisätietoja olen etsinyt Suomessa ja ulkomailla ilmestyneistä tietokirjoista ja muistelmista. Olen myös haastatellut entisiä gulag-vankeja itse. Nämä haastattelut ovat kokoelmassani Kansan arkistossa.

Suuren vainon niin sanotut kansalliset operaatiot vuosina 1937-38 kohdistuivat erityisen ankarina kahteen vähemmistöryhmään, suomalaisiin ja puolalaisiin. Kun tarkastellaan kaikkia tuolloin koko Neuvostoliitossa tuomittuja poliittisia pidätettyjä, käy ilmi, että 51 prosenttia oikeuden eteen joutuneista sai kuolemantuomion. ${ }^{1}$ Tilastoista voi myös päätellä, että suomalaisista vangituista ja tuomituista noin 89 prosenttia teloitettiin. Tämä tapahtui muutaman kuukauden ajanjaksona vainon huippukaudella vuosina 1937-38 ja olisi korkein luku suhteessa kaikkiin muihin vähemmistökansallisiin ryhmiin - sillä varauksella, että venäläisiin tilastoihin voi luottaa. Minun lisäkseni myös muut ovat laskeneet ja arvioineet, että selvästi yli 80 prosenttia suomalaisista tuomituista sai tuolloin kuolemantuomion. Noin 80 prosenttia on myös puolalaisten ja virolaisten suhdeluku. Kaikkien vähemmistökansallisuuksien teloituskeskiarvo oli 73,6 prosenttia.

Pidätysluvuissa suomalaiset sijoittuivat Neuvostoliitossa vasta sijalle 16. Teloitettujen vähemmistökansojen joukossa suomalaiset olivat määrällisesti eli absoluuttisin luvuin kuudennella sijalla, mutta teloitusten suhteellinen osuus nostaa suomalaiset kärkeen. Tilastot vahvistavat nobelisti Czesław Miłoszin havainnon siitä, että venäläiset eivät luottaneet muiden kansallisuuksien kommunisteihin, etenkään puolalaisiin. Numeroiden valossa on selvää, ettei suomalaisiinkaan luotettu.

Joillakin paikkakunnilla tapahtui suuria suomalaisten verilöylyjä. Olen esimerkiksi laskenut ${ }^{2}$, että yhtenä maaliskuisena yönä 1938 Tšeljabinskissä ammuttiin yli 200 suomalaista naista ja miestä. Teloituksia tapahtui samana yönä myös Sverdlovskissa. Syyskuussa 1938 Sisäasiain kansankomissariaatti NKVD ahkeroi myös Neuvosto-Karjalassa. Sen suosituksesta tuomittiin yhtenä päivänä 500 "Suomen vakoojaa"; viitenä perättäisenä päivänä kaikkiaan 1 382 suomalaista, joista 1353 tuomittiin kuolemaan.

Edellisenä vuonna NKVD:n johtaja Nikolai Ježov oli määrännyt, että synnyinmaan pettureiden vaimotkin oli vangittava ja kyydittävä. Pidätetty sai kotietsinnän jälkeen ottaa mukaan alusvaatekerran, pyyhkeen, saippuan ja 50 ruplaa rahaa. Yli 15-vuotiaat lapset oli tuomittava 5-8 vuodeksi vankeuteen, koska eivät olleet ilmiantaneet vanhempiaan. Yli 16-vuotiaat voitiin lähettää gulag-leireille. Vaille vanhempiaan jääneet lapset siirrettiin lastenkoteihin, työpalvelukseen tai hallinnon näkökulmasta luotettavien henkilöiden kasvatettaviksi. Sisarukset erotettiin toisistaan, ja usein heidän nimensä muutettiin.

Jo tuolloin olivat voimassa muutetun rikosoikeuden seuraavat pykälät: terroristijärjestöjen juttujen käsittelyyn saa käyttää enintään 10 